F. J. García-Peñalvo, M. Á. Conde and J. Gonçalves, "Computational thinking and robotics in education," in TEEM'19 Proceedings of the Seventh International Conference on Technological Ecosystems for Enhancing Multiculturality (Leon, Spain, October 16th-18th, 2019), M. Á.

Conde-González, F. J. Rodríguez-Sedano, C. Fernández-Llamas and F. J. García-Peñalvo, Eds. ICPS: ACM International Conference Proceedings Series, pp. 2-5, New York, NY, USA: ACM, 2019. doi: 10.1145/3362789.3362957

\title{
Computational thinking and robotics in education
}

\author{
Francisco José García- \\ Peñalvo \\ GRIAL Research Group \\ Computer Science Department \\ Research Institute for Educational \\ Sciences \\ University of Salamanca \\ 37008 Salamanca, Spain \\ fgarcia@usal.es
}

\author{
Miguel Ángel Conde \\ University of Leon \\ León, Spain \\ mcong@unileon.es
}

\author{
José Gonçalves, José Lima \\ Instituto Politécnico de Bragança \\ Bragança, Portugal \\ \{goncalves, jllima\}@ipb.pt
}

\begin{abstract}
After the computational thinking sessions in the previous 20162018 editions of TEEM Conference, the fourth edition of this track has been organized in the current 2019 edition. Computational thinking is still a very significant topic, especially, but not only, in pre-university education. In this edition, the robotic has a special role in the track, with a strength relationship with the STEM and STEAM education of children at the pre-university levels, seeding the future of our society.
\end{abstract}

\section{KEYWORDS}

Computational thinking, robots, coding in schools, computational thinking skills and curriculum, programming, computer science in K-12, STEM, STEAM.

\section{Introduction}

Nowadays the development of computational thinking [1-6] skills is a real need for future generations of workers that should know, at least, the basic laws of a computer-based society and, without demerit to humanities or social sciences, trying to reduce the current gap with STEM (Science, Technology, Engineering, and Mathematics) [7, 8] and STEAM (Science, Technology, Engineering, Arts, and Mathematics) [9-12] careers.

Several countries have usually adopted several priorities for developing ICT competences from kindergarten to secondary education $[13,14]$, others are trying to $[15,16]$. Most of them are focused on the development of key competences and/or coding skills. Although coding may be very attractive for young students and a very good practice or experience, it could be more interesting to develop students' logical thinking skills and problem-solving skills throughout programming approaches [17$20]$ or through the use of physical devices [21-23] and robots [2426].

This is a very exciting challenge with lots of possibilities regarding coding, robots, mobiles devices, Arduino-based application, game-based learning and so on. Thus, it is very important discuss the experiences that are being developed worldwide in specialized for a with researchers that are working on this field, such as for example TACCLE3 coding [27], VALS [28, 29], W-STEM [30-32] or RoboSTEAM [33, 34] European projects.

Developing computational thinking is not easy due to the students require working the related skills from their early ages, something that use to be linked to STEM or STEAM education. These disciplines that have shown to be necessary in order to have more efficient workers in our digital society [35]. However, integrating and fostering STEM/STEAM in our current educational landscape is very complex because it is not easy to summarize all this knowledge in a set of subjects, and it cannot be focused only on some subjects or courses.

Following the previous editions of this track in TEEM Conference [36-38], this space is devoted to identifying, sharing, and valorizing best practices and experiences (including technological and methodological issues) that focused on the development of computational thinking and related skills and competences [39] in any level of pre-university education and also at the university level. We have the aim to explore and debate these issues related to the education with a critical and solid base of the future generation in technological aspects to help them to tackle the problems they will have to face with an open innovation orientation [40], with the final goal to be useful to the society in general $[41,42]$.

\section{Papers in the track}

Now, the seven accepted papers will be briefly presented.

\subsection{Initial learning scenarios based on the computational thinking evaluation for the course Programming fundamentals at INACAP}

In this paper Rojas-López and García-Peñalvo [43] introduce the design and the planning of initial learning scenarios for the course Programming Fundamentals, from the evaluation of computational thinking to new students of the careers Computer 
engineering and Programmer analyst of the Technological University of Chile and Training Center Technical respectively at INACAP, to increase the motivation and autonomy of study through the recognition of skills and the use of the instructional design of the face-to-face course.

\subsection{Interpretation of computational thinking evaluation results for enrollment prediction}

Rojas-López and García-Peñalvo [44] advance in their research about the computational thinking evaluation, which has been carried out in order to establish learning scenarios for programming methodology new students at the Technological University of Puebla in México [45-48]. The present work analyzes the results obtained from the computational thinking evaluation to 242 new students, generation 2018 .

\subsection{Learning computational thinking and social skills development in young children through problem solving with educational robotics}

Caballero-Gonzalez et al. [49] present some results obtained in the development of a learning experience in computational thinking and social interaction skills, using problem solving activities and educational robotics in a playful way. The experience involved 46 students and 2 teachers of the first level of primary education of a concerted school in Salamanca, Spain, during the period 20172018. This means the continuation of their previous research outcomes presented in TEEM Conference [50-52].

\subsection{RoboSTEAM - A Challenge Based Learning Approach for integrating STEAM and develop Computational Thinking}

Conde et al. [34] introduce the RoboSTEAM European Project [33] (http://robosteamproject.eu/), which is devoted to defining a methodology and a set of tools that will help learners to develop computational thinking by using/programming PD\&R (Physical Devices and Robotics) in pre-university education stages. The project will also improve teacher education, providing them with a framework for easy STEAM integration in different educational contexts by providing guidelines for good practices and lessons learned adapted to different contexts.

\subsection{Bringing Computational Thinking to Hospital Classrooms}

González-González et al. [53] presents an exploratory case study on an educational intervention that is inclusive and adaptable to the characteristics of hospital classrooms for the teaching of computational thinking in a transversal way and programming without screens and robots, including working with emotions. In this study, 22 boys and girls participated in five sessions developed in a hospital classroom. The results indicate that the intervention has improved the emotional state of the children, as well as their knowledge regarding computational thinking. This research is another example of using computational thinking in different context such as the research previously by this group $[54,55]$.

\subsection{Educational Robotics Summer Camp at IPB: A Challenge based learning case study}

Gonçalves et al. [56] present an educational experiment in the mobile robotics domain within the RoboSTEAM European project RoboSTEAM [33, 34]. The applied approach in the summer camp was a challenge-based learning methodology, being involved in the experiment 3 professors, 4 monitors, working with a group of 16 secondary school students.

\subsection{Predicting Student Failure in an Introductory Programming Course with Multiple Back-Propagation}

Figueiredo et al. [57] propose an early identification of potential problems and immediate response to avoid programming student's failure and reduce dropout rates. Thus, they define a machine-learning (neural network) predictive model of student failure based on the student profile, which is built throughout programming classes by continuously monitoring and evaluating student activities. This means the next step in this research for the authors [58-62]

\section{REFERENCES}

[1] J M Wing. 2006. Computational Thinking. Communications of the ACM 49, 3, 33-35. DOI:10.1145/1118178.1118215.

[2] F. J. García-Peñalvo. 2016. What computational thinking is. Journal of Information Technology Research 9, 3, v-viii.

[3] F. J. García-Peñalvo. 2018. Computational thinking. IEEE Revista Iberoamericana de Tecnologías del Aprendizaje (IEEE RITA) 13, 1, 17-19. DOI:10.1109/RITA.2018.2809939.

[4] M. Zapata-Ros. 2015. Pensamiento computacional: Una nueva alfabetización digital. RED, Revista de Educación a distancia 46.

[5] C. S. González-González. 2019. State of the art in the teaching of computational thinking and programming in childhood education. Education in the Knowledge Society 20. DOI:10.14201/eks2019_20_a17.

[6] M. Zapata-Ros. 2019. Computational Thinking Unplugged. Education in the Knowledge Society 20. DOI:10.14201/eks2019_20_a18.

[7] M. S. Ramírez-Montoya (Ed.). 2017. Handbook of Research on Driving STEM Learning With Educational Technologies. IGI Global, Hershey PA, USA.

[8] Todd R. Kelley and J. Geoff Knowles. 2016. A conceptual framework for integrated STEM education. International fournal of STEM Education 3, 1, 11. DOI:10.1186/s40594-0160046-z.

[9] E. Hamner and J. Cross. 2013. Arts \& Bots: Techniques for distributing a STEAM robotics program through K-12 classrooms. In Proceedings of 2013 IEEE Integrated STEM Education Conference (ISEC) (March 9th, 2013, Princeton, Nf, USA) IEEE, USA, 1-5. DOI:10.1109/ISECon.2013.6525207.

[10] Margaret E. Madden, Marsha Baxter, Heather Beauchamp, Kimberley Bouchard, Derek Habermas, Mark Huff, Brian Ladd, Jill Pearon, and Gordon Plague. 2013. Rethinking STEM Education: An Interdisciplinary STEAM Curriculum. Procedia Computer Science 20, 541-546. DOI:10.1016/j.procs.2013.09.316. 
[11] Michelle H. Land. 2013. Full STEAM Ahead: The Benefits of Integrating the Arts Into STEM. Procedia Computer Science 20, 547-552. DOI:10.1016/j.procs.2013.09.317.

[12] D. A. Sousa and T. Pilecki. 2013. From STEM to STEAM: Using Brain-Compatible Strategies to Integrate the Arts. Corwin, Thousand Oaks, California, USA.

[13] Anja Balanskat and Katja Engelhardt. 2015. Computing our future. Computer programming and coding Priorities, school curricula and initiatives across Europe. European Schoolnet.

[14] M. Jovanov, E. Stankov, M. Mihova, S. Ristov, and M. Gusev. 2016. Computing as a new compulsory subject in the Macedonian primary schools curriculum. In Proceedings of the 2016 IEEE Global Engineering Education Conference (EDUCON 2016) (10-13 April 2016, Abu Dhabi, United Arab Emirates) IEEE, USA, 680-685. DOI:10.1109/EDUCON.2016.7474623.

[15] J. Á. Velázquez Iturbide, A. Bahamonde, S. Dabic, M. J. Escalona, F. Feito, S. Fernández Cabaleiro, B. Ferrero Martín, N. Garay Vitoria, J. C. García, L. García Borgoñón, M. García Martínez, J. García Molina, I. García Varea, M. Hermenegildo Salinas, E. Larraza Mendiluze, F. Llorens Largo, J. A. Mateos, A. Moratel Muñoz, D. Mozos, E. Pimentel, B. Sahelices, M. Toro, and M. Zapata Ros. 2018. Informe del Grupo de Trabajo SCIE/CODDII sobre la enseñanza preuniversitaria de la informática. Sociedad Científica Informática de España, Conferencia de Decanos y Directores de Ingeniería Informática.

[16] J. Á. Velázquez-Iturbide. 2018. Report of the Spanish Computing Scientific Society on Computing Education in Pre-University Stages. In Proceedings TEEM'18. Sixth International Conference on Technological Ecosystems for Enhancing Multiculturality (Salamanca, Spain, October 24th26th, 2018), F.J. García-Peñalvo Ed. ACM, New York, NY, USA, 2-7. DOI:10.1145/3284179.3284180.

[17] F. J. García-Peñalvo and J. A. Mendes. 2018. Exploring the computational thinking effects in pre-university education. Computers in Human Behavior 80, 407-411. DOI:10.1016/j.chb.2017.12.005.

[18] A. M. Pinto-Llorente, S. Casillas-Martín, M. CabezasGonzález, and F. J. García-Peñalvo. 2018.Building, coding and programming 3D models vian a visual programming environment. Quality \& Quantity) 52, 6, 2455-2468. DOI:10.1007/s11135-017-0509-4.

[19] S. Y. Lye and J. H. L. Koh. 2014. Review on teaching and learning of computational thinking through programming: What is next for K-12? Computers in Human Behavior 41, 5161. DOI:10.1016/j.chb.2014.09.012.

[20] G. Michaelson. 2015. Teaching Programming with Computational and Informational Thinking. Journal of Pedagogic Development 5, 1 (Mar), 51-65.

[21] F. J. García-Peñalvo, D. Reimann, and C. Maday. 2018. Introducing Coding and Computational Thinking in the Schools: The TACCLE 3 - Coding Project Experience. In Computational Thinking in the STEM Disciplines. Foundations and Research Highlights, M.S. Khine Ed. Springer, Cham, Switzerland, 213-226. DOI:10.1007/978-3319-93566-9_11.

[22] Daniela Reimann and Christiane Maday. 2016. Smart Textile objects and conductible ink as a context for arts based teaching and learning of computational thinking at primary school. In Proceedings of the Fourth International Conference on Technological Ecosystems for Enhancing Multiculturality (TEEM'16) (Salamanca, Spain, November 2-4, 2016), F.J. García-Peñalvo Ed. ACM, New York, NY, USA, 31-35. DOI:10.1145/3012430.3012493.

[23] D. Reimann and C. Maday. 2017. Enseñanza y aprendizaje del modelado computacional en procesos creativos y contextos estéticos. Education in the Knowledge Society 18, 3, 87-97. DOI:10.14201/eks20171838797.

[24] C. Fernández-Llamas, M. Á. Conde-González, F. J. Rodríguez-Lera, F. J. Rodríguez-Sedano, and F. J. GarcíaPeñalvo. 2018. May I teach you? Students' behavior when lectured by robotic vs. human teachers. Computers in Human Behavior 80, 460-469. DOI:10.1016/j.chb.2017.09.028.

[25] A. García-Valcárcel Muñoz-Repiso and Y. A. Caballero González. 2019. Robotics to develop computational thinking in early Childhood Education. Comunicar 59, 63-72. DOI:10.3916/C59-2019-06.

[26] S. Atmatzidou and S. Demetriadis. 2016. Advancing students' computational thinking skills through educational robotics: A study on age and gender relevant differences. Robotics and Autonomous Systems 75(Jan), 661-670. DOI:10.1016/j.robot.2015.10.008.

[27] F. J. García-Peñalvo. 2016. A brief introduction to TACCLE 3 - Coding European Project. In 2016 International Symposium on Computers in Education (SIIE 16), F.J. GarcíaPeñalvo and J.A. Mendes Eds. IEEE, USA. DOI:10.1109/SIIE.2016.7751876.

[28] F. J. García-Peñalvo, J. Cruz-Benito, M. Á. Conde, and D. Griffiths. 2014. Virtual placements for informatics students in open source business across Europe. In 2014 IEEE Frontiers in Education Conference Proceedings (October 22-25, 2014 Madrid, Spain) IEEE, USA, 2551-2555. DOI:10.1109/FIE.2014.7044411.

[29] F. J. García-Peñalvo, J. Cruz-Benito, D. Griffiths, and A. P. Achilleos. 2016. Virtual placements management process supported by technology: Proposal and firsts results of the Semester of Code. IEEE Revista Iberoamericana de Tecnologías del Aprendizaje (IEEE RITA) 11, 1, 47-54. DOI:10.1109/RITA.2016.2518461.

[30] F. J. García-Peñalvo. 2019. Women and STEM disciplines in Latin America. The W-STEM European Project. fournal of Information Technology Research 12, 4.

[31] F. J. García-Peñalvo. 2019. W-STEM Project Overview. In Proceedings of the W-STEM Erasmus+ project Kick-Off (Salamanca, Spain, March 25-27, 2019 2019). W-STEM consortium. DOI:10.5281/zenodo.2605431.

[32] A. García-Holgado, F. J. García-Peñalvo, and A. Camacho Díaz. 2019. Engaging women into STEM in Latin America: W-STEM project. In Seventh International Conference on Technological Ecosystems for Enhancing Multiculturality TEEM 2019 ACM, León, Spain.

[33] Robosteam Consortium. 2019. RoboSTEAM Project. In Proceedings of the RoboSTEAM Erasmus+ project Kick-Off (Bragança, Portugal, February 15-16, 2019 2019). RoboSTEAM consortium. DOI:10.5281/zenodo.2575066.

[34] M. Á. Conde, C. Ferández-Llamas, J. F. Ribeiro Alves, M. J. Ramos, S. Celis Tena, J. Gonçalves, J. Lima, D. Reimann, I. Jormanainen, and F. J. García-Peñalvo. 2019. RoboSTEAM A Challenge Based Learning Approach for integrating STEAM and develop Computational Thinking. In Seventh 
International Conference on Technological Ecosystems for Enhancing Multiculturality - TEEM 2019 ACM, León, Spain.

[35] European Commission. 2018. The European Higher Education Area in 2018: Bologna Process Implementation Report Education, Audiovisual and Culture Executive Agency Education and Youth Policy Analysis, Brussels, Belgium. DOI:10.2797/265898.

[36] F. J. García-Peñalvo and J. Cruz-Benito. 2016. Computational thinking in pre-university education. In Proceedings of the Fourth International Conference on Technological Ecosystems for Enhancing Multiculturality (TEEM'16) (Salamanca, Spain, November 2-4, 2016), F.J. García-Peñalvo Ed. ACM, New York, NY, USA, 13-17. DOI:10.1145/3012430.3012490.

[37] F. J. García-Peñalvo. 2017. Computational thinking issues. In Fifth International Conference on Technological Ecosystems for Enhancing Multiculturality (TEEM'17) (Cádiz, Spain, October 18-20, 2017) J.M. Dodero, M.S. Ibarra Sáiz and I. Ruiz Rube Eds. ACM, New York, NY, USA, Article 1. DOI:10.1145/3144826.3145349.

[38] F. J. García-Peñalvo. 2018. Computational thinking and programming education principles. In TEEM'18 Proceedings of the Sixth International Conference on Technological Ecosystems for Enhancing Multiculturality (Salamanca, Spain, October 24th-26th, 2018), F.J. García-Peñalvo Ed. ACM, New York, NY, USA, 14-17. DOI:10.1145/3284179.3284184.

[39] E. Morales-Morgado, F. J. García-Peñalvo, R. CamposOrtuño, and C Astroza-Hidalgo. 2013. Desarrollo de competencias a través de objetos de aprendizaje. RED Revista de Educación a Distancia, 36.

[40] M. S. Ramírez-Montoya and F. J. García-Peñalvo. 2018. Cocreation and open innovation: Systematic literature review. Comunicar 26, 54, 9-18. DOI:10.3916/C54-2018-01.

[41] F. J. García-Peñalvo. 2016. The Third Mission. Education in the Knowledge Society 17, 1, 7-18. DOI:10.14201/eks2016171718.

[42] F. J. García-Peñalvo and M. S. Ramírez Montoya. 2016. Technology cases for improving the university Third Mission. Journal of Cases on Inførmation Technology 18, 4, vviii.

[43] A. Rojas-López and F. J. García-Peñalro. 2019. Initial learning scenarios based on the computational thinking evaluation for the course Programming fundamentals at INACAP. In Seventh International Conference on Technological Ecosystems for Enhancing Multiculturality TEEM 2019 ACM, León, Spain.

[44] A. Rojas-López and F. J. García-Peñalvo. 2019. Interpretation of computational thinking evaluation results for enrollment prediction. In Seventh International Conference on Technological Ecosystems for Enhancing Multiculturality TEEM 2019 ACM, León, Spain.

[45] A. Rojas-López and F. J. García-Peñalvo. 2016. Personalized contents based on cognitive level of student's computational thinking for learning basic competencies of programming using an environment b-learning. In Proceedings of the Fourth International Conference on Technological Ecosystems for Enhancing Multiculturality (TEEM'16) (Salamanca, Spain, November 2-4, 2016), F.J. García-Peñalvo Ed. ACM, New York, NY, USA, 1139-1145. DOI:10.1145/3012430.3012660.

[46] A. Rojas-López and F. J. García-Peñalvo. 2017. Personalized education using computational thinking and b-learning environment: classroom intervention. In Fifth International
Conference on Technological Ecosystems for Enhancing Multiculturality (TEEM’17) (Cádiz, Spain, October 18-20, 2017) J.M. Dodero, M.S. Ibarra Sáiz and I. Ruiz Rube Eds. ACM, New York, NY, USA, Article 9. DOI:10.1145/3144826.3145357.

[47] A. Rojas-López and F. J. García-Peñalvo. 2018. Increase of confidence for the solution of problems in preuniversity students through Computational Thinking. In TEEM'18 Proceedings of the Sixth International Conference on Technological Ecosystems for Enhancing Multiculturality (Salamanca, Spain, October 24th-26th, 2018) ACM, New York, NY, USA, 31-35. DOI:10.1145/3284179.3284187.

[48] A. Rojas-López. 2017. Intervención de tres estrategias educativas para cursos de programación en educación superior. Education in the Knowledge Society 18, 4, 21-34. DOI:10.14201/eks20171842134.

[49] Y. A. Caballero-González, A. García-Valcárcel MuñozRepiso, and A. García- Holgado. 2019. Learning computational thinking and social skills development in young childrenthrough problem solving with educational robotics. In Seventh International Conference on Technological Ecosystems for Enhancing Multiculturality TEEM 2019 ACM, Leơn, Spain.

[50] Y. A. Caballero González and A. García-Valcárcel MuñozRepiso. 2017. Development of computational thinking and collaborative learning in kindergarten using programmable educational robots: a teacher training experience. In Fifth International Conference on Technological Ecosystems for Enhancing Multiculturality (TEEM'17) (Cádiz, Spain, October 18-20, 2017) J.M. Dodero, M.S. Ibarra Sáiz and I. Ruiz Rube Eds. ACM, New York, NY, USA, Article 5. DOI: $10.1145 / 3144826.3145353$.

[51] Y. A. Caballero González and A. García-Valcárcel MuñozRepiso. 2017. Development of computational thinking skills and collaborative learning in initial education students through educational activities supported by ICT resources and programmable educational robots. In Fifth International Conference on Technological Ecosystems for Enhancing Multiculturality (TEEM'17) (Cádiz, Spain, October 18-20, 2017) J.M. Dodero, M.S. Ibarra Sáiz and I. Ruiz Rube Eds. ACM, New York, NY, USA, Article 103. DOI:10.1145/3144826.3145450.

[52] Y. A. Caballero González and A. García-Valcárcel MuñozRepiso. 2018. A robotics-based approach to foster programming skills and computational thinking: Pilot experience in the classroom of early childhood education. In Sixth International Conference on Technological Ecosystems for Enhancing Multiculturality (TEEM 2018) ACM, Salamanca, Spain.

[53] C. S. González-González, L. Cáceres-García, and V. ViolantHolz. 2019. Bringing Computational Thinking to Hospital Classrooms. In Seventh International Conference on Technological Ecosystems for Enhancing Multiculturality TEEM 2019 ACM, León, Spain.

[54] C. González-González, E. Herrera González, L. Moreno Ruiz, A. Infante-Moro, and M. D. Guzmán-Franco. 2018. Teaching computational thinking to Down syndrome students. In Sixth International Conference on Technological Ecosystems for Enhancing Multiculturality (TEEM 2018) ACM, Salamanca, Spain. 
[55] C. González-González, E. Herrera González, L. Moreno Ruiz, N. Reyes-Alonso, S. Hernández-Morales, M. D. GuzmánFranco, and A. Infante-Moro. 2019. Computational Thinking and Down Syndrome: An Exploratory Study Using the KIBO Robot. Informatics 6, 2. DOI:10.3390/informatics6020025.

[56] J. Gonçalves, J. Lima, T. Brito, L. Brancalião, C. Camargo, V. Oliveira, and M. Á. Conde. 2019. Educational Robotics Summer Camp at IPB: A Challenge based learning case study. In Seventh International Conference on Technological Ecosystems for Enhancing Multiculturality - TEEM 2019 ACM, León, Spain.

[57] J. Figueiredo, N. Lopes, and F. J. García-Peñalvo. 2019. Predicting Student Failure in an Introductory Programming Course with Multiple Back-Propagation. In Seventh International Conference on Technological Ecosystems for Enhancing Multiculturality - TEEM 2019 ACM, León, Spain.

[58] J. Figueiredo and F. J. García-Peñalvo. 2017. Improving Computational Thinking Using Follow and Give Instructions. In Fifth International Conference on Technological Ecosystems for Enhancing Multiculturality (TEEM'17) (Cádiz, Spain, October 18-20, 2017) J.M. Dodero, M.S. Ibarra Sáiz and I. Ruiz Rube Eds. ACM, New York, NY, USA, Article 3. DOI:10.1145/3144826.3145351.
[59] J. Figueiredo and F. J. García-Peñalvo. 2017. Desenvolver o Pensamento Computacional Usando Seguir e Dar Instruções. In TICAI 2017: TICs para el Aprendizaje de la Ingeniería, A. Lago Ferreiro, A. Fidalgo and O. Da Silva Eds. IEEE, Sociedad de Educación: Capítulos Español y Portugués, USA, 101-108.

[60] J. Figueiredo and F. J. García-Peñalvo. 2018. Building Skills in Introductory Programming. In TEEM'18 Proceedings of the Sixth International Conference on Technological Ecosystems for Enhancing Multiculturality (Salamanca, Spain, October 24th-26th, 2018) ACM, New York, NY, USA, 46-50. DOI: $10.1145 / 3284179.3284190$.

[61] J. Figueiredo, N. Gomes, and F. J. García-Peñalvo. 2016. neCourse for Learning Programming. In Proceedings of the Fourth International Conference on Technological Ecosystems for Enhancing Multiculturality (TEEM'16) (Salamanca, Spain, November 2-4, 2016), F.J. García-Peñalvo Ed. ACM, New York, NY, USA, 549-553. DOI:10.1145/3012430.3012572.

[62] J. A. Q. Figueiredo. 2017. How to improve computational thinking: A case study. Education in the Knowledge Society 18, 4, 35-51. DOI:10.14201/eks20171843551.

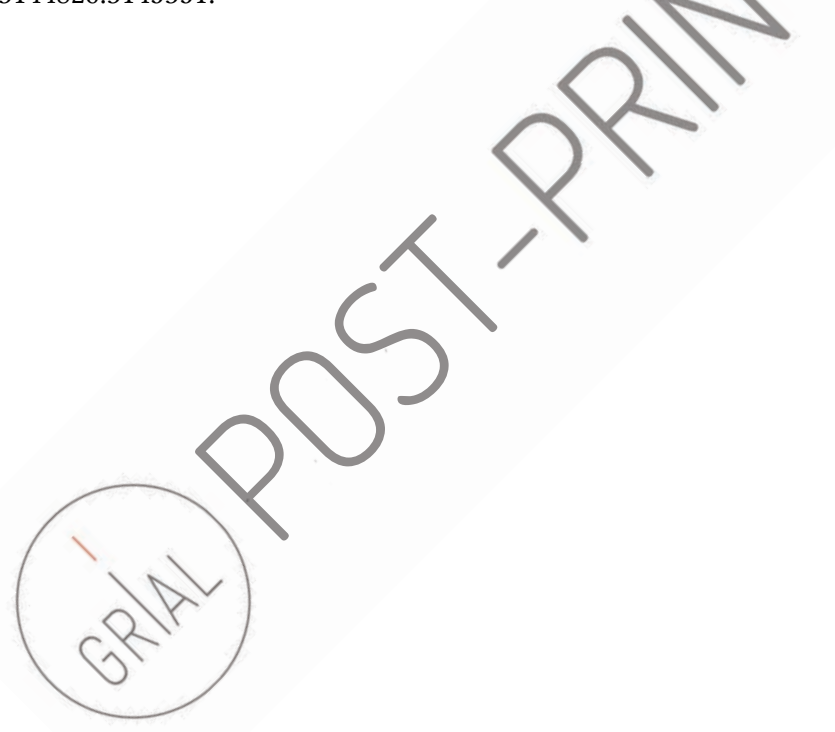

